\title{
Description of Atylotus nagatomii n. sp. from Kyushu Island, Japan (Diptera, Tabanidae)
}

\author{
Hirofumi Hayakawa* \\ Tohoku National Agricultural Experiment Station, Morioka 020-01, Japan
}

(Received: June 15, 1992)

Key words: new species, Atylotus nagatomii, Tabanidae, Japan.

\begin{abstract}
Atylotus nagatomii n. sp. is described based on male and female materials from Kyushu Island, Japan. This species is related to Atylotus bivittateinus Takahasi, 1962, but can be easily distinguished from it by the dark abdominal tergites with a paler median stripe, which is especially distinct in the male, and by rudimentary middle callus on frons and dense black hairs on maxillary palpi in the female.
\end{abstract}

In examination of Prof. Akira Nagatomi's collection of tabanid specimens preserved in the Entomological Laboratory, Faculty of Agriculture, Kagoshima University, an unknown Atylotus species was found (Hayakawa, 1992). Close study revealed that this species is new to science.

\section{Atylotus nagatomii n. sp.}

Female (Fig. 1). Length 14-16 mm.

Medium-size, rather robust, yellowish-grey species. Flagellum of antennae stout, yellowish-orange. Frons narrow with a small quadrate basal callus and a rudimentary middle callus. Wings hyaline. Legs pale brown, darker distally. Abdomen yellowish-grey with distinct submedian black stripes forming a pale median stripe on tergites.

Head: very large, about 1.3 times as wide as thorax. Eyes brownish-yellow to dark brown in dried specimens, bare with a dark brown band on level with basal callus becoming indefinite in the middle part of the eye. Ocellar tubercle absent. Frons narrow, about 4.5 times as high as basal width, slightly

* 早川博文：農林水産省東北農業試験場畜産部 （兵020-01 盛岡市下欴川字赤平 4） widened above, pale yellowish pollinose with short pale yellowish hairs, mixed with short black hairs. Vertex slightly depressed, covered with black hairs. Basal callus shiny dark brown to black, small, about quadrate, broadly separated from eye margins and subcallus; middle callus shiny dark brown to black, very small, or entirely absent in some specimens. Subcallus concolorous pollinose with frons. Face and cheeks pale yellowish pollinose with long pale yellowish hairs.

Antennae: stout, shorter than the length of head. Scape yellow to yellowish-orange with short black hairs, mixed with pale yellowish hairs basally, about as long as width, half the length of basal segment of flagellum, widened apically. Pedicel small, cup-like, concolorous with scape, covered with short black hairs. Flagellum yellowish-orange to yellowish-brown, darker at stylus, rather long; basal segment compressed, about 1.5 times as long as width, tapering toward apex; dorsal process dull with some short black hairs; stylus slender and somewhat shorter than the length of basal segment, composed of 4 annulations. Maxillary palpi pale yellow, a little shorter than proboscis; first segment short, covered with long pale yellowish hairs; second segment stout, roughly elongate- 

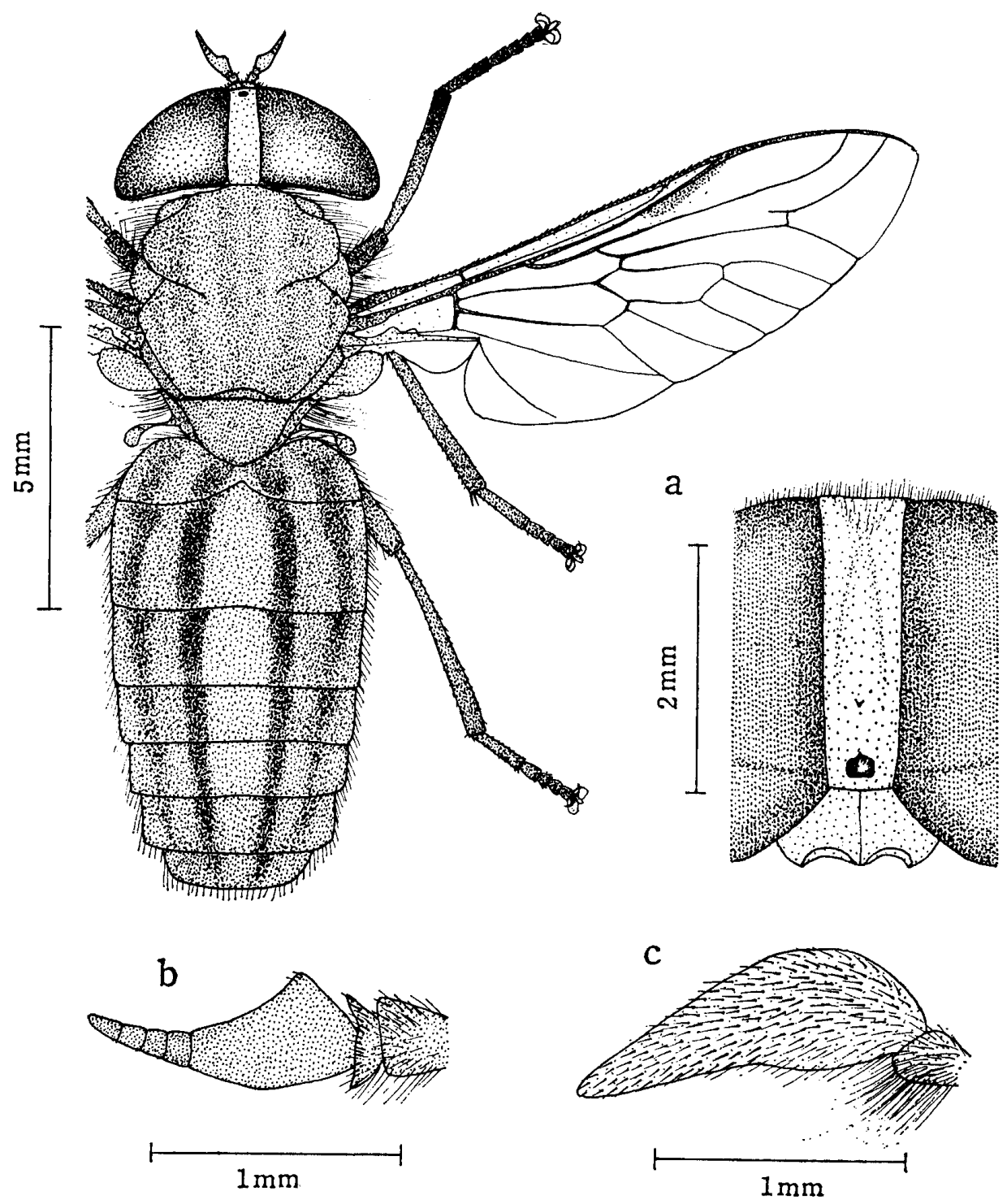

Fig. 1 Female of Atylotus nagatomii n. sp. a: frons. b: antenna. c: palpus.

fusiform, about 3.1 times as long as width, covered with short black hairs, but with short pale yellowish hairs at lower base. Proboscis yellowish-brown, stout, about $3 / 5$ the length of head.

Thorax: slightly longer than width. Scutum and scutellum yellowish-grey, covered mostly with short pale yellowish hairs, mixed with short black hairs. Paler stripes on scutum somewhat indistinct. Humeral calli pale yellow with pale yellowish hairs. Notopleural lobes pale yellow with long pale yellowish hairs, mixed sparsely with long black hairs. Some tufts of pale yellowish hairs on supraalar and postalar calli. Pleura, sternum and fore coxae pale yellow with long pale yellow- ish hairs.

Wings: slightly shorter than body length, hyaline except some yellowish tints at base and around costal cell. Pterostigma pale brown, somewhat indefinite. Veins pale brown; vein $R_{4}$ with rather long appendix. Gell $\mathbf{R}_{5}$ open. Halteres pale brown, but the knobs vividly yellow.

Legs: femora pale brown, but fore femora much darker, covered with long black hairs. Tibiae pale brown, covered with short black hairs; fore tibiae blackish at distal half. Tarsi brown to black, covered with short black hairs.

Abdomen: rather elongate-oval in shape. Dorsum yellowish-grey, with black submedian 


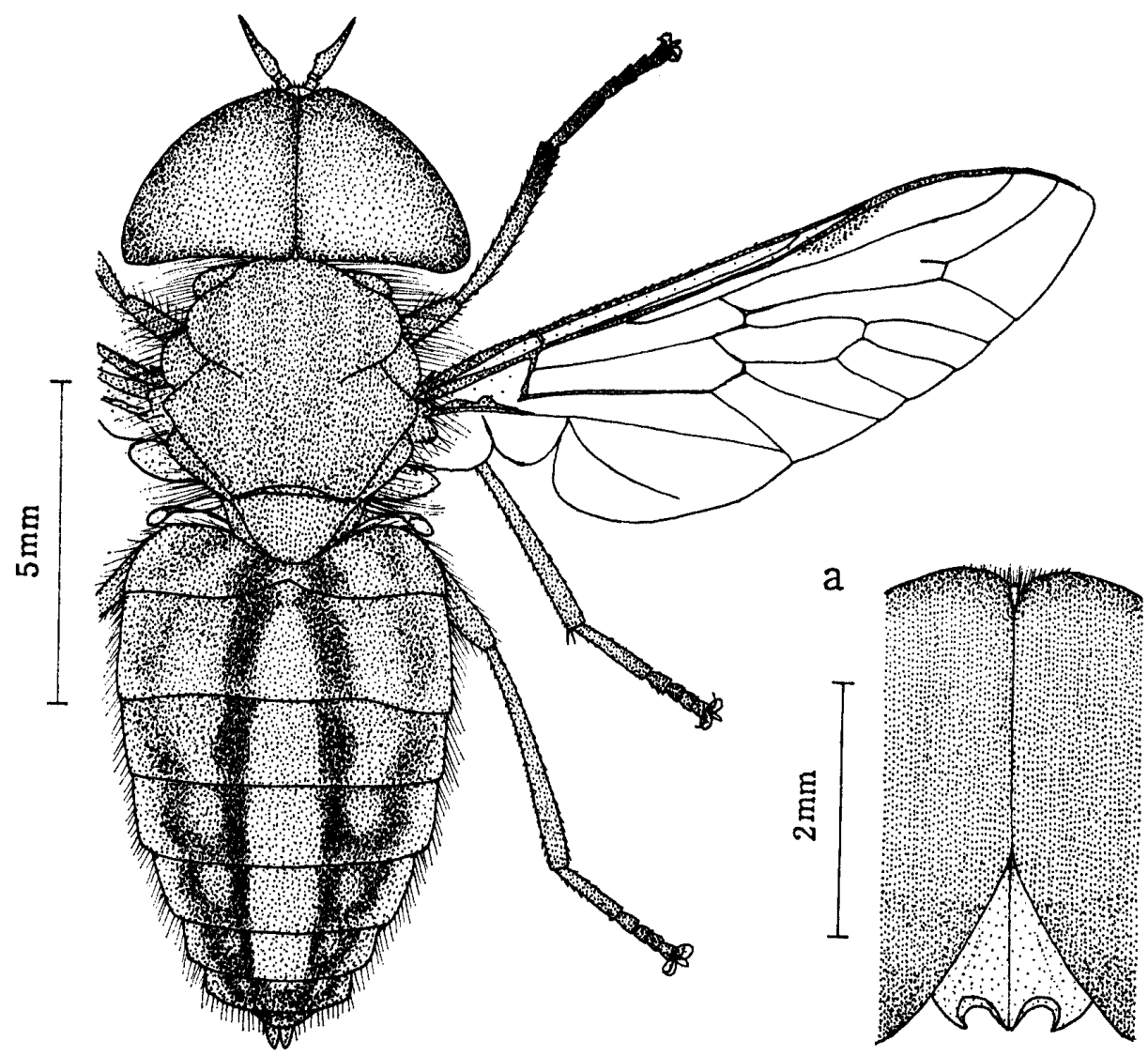

C
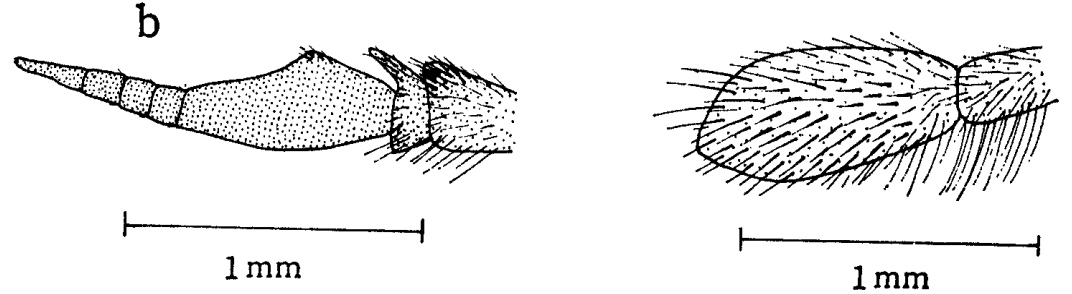

Fig. 2 Male of Atylotus nagatomii n. sp.

a: frons. b: antenna. c: palpus.

stripes forming a paler median stripe, and with somewhat indistinct sublateral stripes on tergite 1-6, covered with short pale yellowish hairs on paler parts and short black hairs on darker parts. Venter entirely yellowish-grey, covered with short pale yellowish hairs.

Male (Fig. 2). Length 14-16 mm.

Head: similar to female, but much wider than thorax. Eyes bare, contiguous; large and small facets well differentiated with almost straight line; small facets occupy lower half, much darker. Ocellar tubercle pale yellow, very small, sunken. Frontal triangle pale yellowish pollinose. Face and cheeks pale yellow, covered densely with long pale yellowish hairs.

Antennae: very slender in flagellum. Maxillary palpi much shorter than proboscis; second segment elongate-oval, orange-yellow, covered with long black hairs, inter-mixed with pale yellowish hairs at base.

Thorax, wings and legs: as in female.

Abdomen: more pointed. Median stripe on dorsum distinct, much paler; sublateral stripes somewhat indistinct with an indefinite yellowish-orange spot on tergites 1 to 3 .

Type series. Holotype; $\$$, Ichiki-kaigan, Kagoshima-ken, Kyushu Island, 22 May, 1984, A. Nagatomi leg. Allotype; $\hat{\alpha}$, Ichiki- 
kaigan, Kagoshima-ken, Kyushu Island, 22 May, 1984, A. Nagatomi leg. Paratypes; $2 \%$ ㅇ Ichiki-kaigan, Kagoshima-ken, Kyushu Island, 22 May, 1984, A. Nagatomi leg; $1 \hat{o}$, Ichiki-cho, Kagoshima-ken, Kyushu, 22 May, 1965, R. Ohishi leg; 5 ồ $\hat{o}$, Ichikikaigan, Kagoshima-ken, Kyushu, 8 May, 1984, A. Nagatomi leg. Holotype, allotype and paratypes are deposited in the Laboratory of Systematics, National Institute of Agro-Environmental Sciences in Tsukuba.

Distribution. Kyushu Island, Japan.

Remarks. The present species is most closely related to Atylotus bivittateinus Takahasi, 1962 (Takahasi, 1962). However, it is distinguishable from the latter by the following features; somewhat larger body size; dark colour of abdominal tergites with a paler median stripe which is more distinct in the male; rudimentary middle callus on frons in the female and dense black hairs on maxillary palpi.

Immature stages of the present species are not known. However, as all of the adult specimens were collected from coastal areas, its larval habitat may be in tidelands similar to Atylotus suzukii (Hayakawa, 1981). It is uncertain whether this species is a bloodsucker or not.

\section{REFERENGES}

Hayakawa, H. (1981): Description of Atylotus suzukii $\mathrm{n}$. sp. from Kyushu, Shikoku and Tsushima Islands, Japan (Diptera, Tabanidae). Jpn. J. Sanit. Zool., 32: 105-110.

Hayakawa, H. (1992): List of Tabanidae (Diptera) preserved at Professor Akira Nagatomi of Agriculture Department, Kagoshima University. Misc. Publ. Tohoku Natl. Exp. Stn., 12: 63-74 (in Japanese with English summary).

Takahasi, H. (1962): Fauna japonica, Tabanidae (Insecta), 143 pp., Biogeographical Society of Japan, National Science Museum, Tokyo.

\section{摘 要} アブの 1 新種 Atylotus nagatomii n. sp.
ナガトミキイロアブの記載

鹿児島県日置郡市来町の海岸で採集された標本に基 ぶいて, 新種 Atylotus nagatomii n. sp. ナガトミキ イロアブを記載した。本種は Atylotus bivittateinus Takahasi フタスジアブに酷似するが，体がやや大き いこと，雌の眼間区の中額瘤が痕跡程度か欠いている

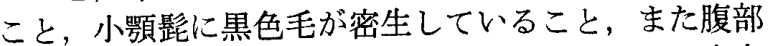
背面がフタスジアブより暗色を帯びた黄灰色で, 中央 縦条が灰白色で明瞭であることにより区別できる。 